\title{
Involving University Stakeholders in Upgrading the Fostering of Students' Readiness to Embark on a Career
}

\author{
Taras O. Olefirenko and Valentyna I. Bobrytska \\ National Pedagogical Dragomanov University, Kyiv, Ukraine \\ https://orcid.org/0000-0002-3278-8125 \\ https:// orcid.org/0000-0002-1742-0103
}

\section{Nina G. Batechko}

National University of Life and Environmental Science of Ukraine, Kyiv, Ukraine https://orcid.org/0000-0002-3772-4489

\author{
Tatiana D. Reva and Oksana M. Chkhalo \\ Bogomolets National Medical University, Kyiv, Ukraine \\ https:// orcid.org/0000-0002-3367-5931 \\ https://orcid.org/0000-0002-8874-4674
}

\begin{abstract}
The purpose of the study was to identify how stakeholders of higher education can influence the quality of the educational process and students' readiness to embark on a career. The study used qualitative and quantitative methods sequentially with the quantitative method predominating. It relied on a survey research design and quasiexperiment with some features of a descriptive case study such as conducting observations by the external stakeholders and administering measurements. The study addressed the issues related to curriculum governance, instruction, learning assessment, and teaching resources. It also eliminated the loopholes in lecturers' attempts to foster the students' readiness to build a career. It enabled an objective and unbiased evaluation of the overall students' professional efficacy during the students' job internships. The baseline survey showed that the students and lecturers reported that they experienced limited satisfaction with the programmes. The self-branding project influenced the students' academic efficiency and career development skills positively. The mean value for the effect size $d$ was 0.67 , indicating that it was large and statistically significant. The observation report provided by representatives of the host organizations implied that the representatives of the host companies were generally pleased with the quality of the occupational readiness of the students. The study will benefit the researchers and practitioners in terms of building long-term relationships and sharing responsibility for the quality of professional training of the students.
\end{abstract}

Keywords: educational process upgrade; higher education; stakeholders; students' career readiness 


\section{Introduction}

Undeniably, being career-ready for a student requires more than just being academically proficient. Employability has been a skill gap in the labour market and higher education in Ukraine for the past decade (OECD Eurasia, 2015). Recent studies suggest that this gap can be addressed through reshaping skills strategy at the national and legislative levels, designing tailored skills' policies based on the sector's needs, developing and implementing a system of on-thejob training at the university level, establishing a dialogue between educational institutions and employers, and introducing educational reforms while monitoring and evaluating the policy change effects (Bobrytska et al., 2020; Carpio et al., 2017).

Involving both internal and external stakeholders of higher education in upgrading the educational process to make it focused on fostering students' readiness to build a career is of growing importance (Bobrytska et al., 2020; Borg et al., 2017; Langrafe et al., 2020). This involvement of a variety of stakeholders is aimed at giving meaning to career-building which is leveraged by integrating that meaning into academic curricula and instruction. Furthermore, all stakeholders share responsibility for the students' learning outcomes and facilitating the effective transition of the students from the university to work (Yamashita \& Cheang, 2019).

However, though considered effective, the university educational process underperforms in equipping students with vital skills and tools for their career management. This increases the graduates' vulnerability in the currently unstable labour market (Lynch, 2017). In the context of higher education in Ukraine, Savga et al. (2018) imply that this happens because higher education institutions need more efficient models and methods for identifying and classifying their stakeholders. The institutions should use reliable assessment methods to identify the interests, degree of involvement, and influence of their stakeholders. Moreover, the instructions should boost the involvement of stakeholders from just the context of the university activities to governance and quality assurance. The researchers conclude that these issues indirectly influence student recruitment and satisfaction, the university's policies and strategies, and the university's income which results in an unfavourable public image of the institution and a disadvantageous position of the students in the job market. It seems that institutions and stakeholders are generally interdependent. Establishing and maintaining relationships between them is becoming a priority goal for universities in Ukraine.

The above shows that there is a need for more research and sharing of best practices in terms of consolidating the efforts of stakeholders of higher education to address the issues of students' readiness to embark on their careers. This need is caused by the constantly increasing complexity of the university education system. This cooperation will benefit the students, instructors, and employers because the graduates' professional efficacy itself will promote the institutional image as well as the image of the teachers. Employers, in turn, will reduce the costs of hiring the right people at a reasonable salary. 


\section{Literature review}

The literature review found that, though not commonly established in practice, the internal and external stakeholders are involved in shaping higher education for a variety of purposes. This involvement takes different forms and modes (Franco et al, 2019). The recent trend of involving alumni, companies, and organisations in education is related to the transition from the elite status of education to mass education based on equality of opportunity with a focus on the future of universal education (Fagrell et al., 2020). Previous research on the involvement of the external stakeholders in higher education reveals this practice from the perspective of their participation in quality assurance of institutions and governance (Beerkens \& Udam, 2017). The latter are both reported to increase the effectiveness of the overall functioning of the university, the education programmes, and the satisfaction of students and employers alike (Ulewicz, 2017).

The involvement of stakeholders is associated with their contribution to the quality of the overall educational output. Wiśniewska et al. (2014) outline both institutional internal and external benefits. These include transmitting the cutting-edge knowledge to the students, shaping the students' particular traits and skills by serving as an example to graduates, adjusting students to their future professional settings and contexts, and enjoying institutional external benefits such as the competitiveness of the educational instruction and students in the job market.

The quality of education is related to the quality of teaching which is seen as a combination of a degree of perfection, the results of actions, and an assessment approach (Costa \& Araújo, 2018). According to Filho and Brandli (2016), the consolidation of the efforts of experts in instruction and experts in graduates' professional sphere can strengthen and boost the educational capacities of the universities. Concerning governance, studies highlight the involvement of the stakeholders of higher education in strategic planning and policy-shaping. This has proven to be an alternative to the conventional law-making procedure in the sphere of education (Bobrytska et al., 2020). However, some studies express scepticism about the effectiveness and necessity of involving external stakeholders in the governance of institutions. They label them as 'Trojan horses' or 'imaginary friends' who lack expertise in instruction. This practice is neither mandated nor regulated by the state (Magalhães et al., 2018).

The literature reveals the involvement of the stakeholders of higher education in upgrading the educational process through collaborative partnerships in research and lecturing, and facilities' improvement that is important and efficient for institutional sustainable growth (Didham \& Ofei-Manu, 2020). Graham et al. (2012) contend that education crisis time is appropriate for fundamental curriculum development as institutions, educational systems, and instruction methods change owing to 'external shock'. Bobrytska et al. (2020) found that this crisis has caused a shift from an input-based accreditation to an outcome-based scheme in higher education in Ukraine and that a new curriculum framework is needed.

The problem of fostering student's readiness to embark on their careers is in the scope of the debate and research as well (Goins, 2018). This readiness has been 


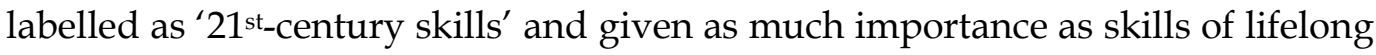
learning and innovation; skills of searching, selecting, using, and generating information; skills of using media and technology; and knowledge of core academic subjects (Alismail \& McGuire, 2015). The students' career readiness is described as a set of skills that can be formed and contextualised for the job within the classroom settings. However, the development of some of the skills requires experience that can be gained only through on-the-job training which necessitates the development of programs of work-related learning. These programmes can offer a range of tools based on the combined use of workrelevant learning within the classroom and the involvement of employers and former students in different forms. Fostering students' career readiness still matters because fewer than one in ten students report that they are ready for employment in the relevant sphere (Busteed, 2015; Goins, 2018; Perna, 2020). The engagement of different stakeholders in reshaping the educational process, its content, and instructional methods improve graduates' employability, learning, and self-renewal competencies (Abelha et al., 2020).

\section{Theoretical framework}

The study relies on the stakeholder theory approach which implements a shift in paradigm in the management of educational organisations aimed at ensuring alignment with new social demands and trends (Freeman et al., 2020). The stakeholder theory attempts to address the issues of identifying and prioritising stakeholders, understanding their interests and demands, balancing the relationships, and engaging them in organisational activities. The theory is gradually gaining acceptance by higher educational institutions (considered to be quasi-commercial ones) because these institutions, in the long run, produce more significant societal value through generating new knowledge and transferring it to a broader community, thus raising the standard of living (Bilodeau et al., 2014; Ferrero-Ferrero et al., 2018). The theory specifies that the organisation becomes more competitive when it unites stakeholders to create tangible and intangible value within the organisation and for the external beneficiaries such as consumers and local communities (Freeman et al., 2020). The essential principle of the theory is that stakeholders will cooperate with the institution when they benefit from that cooperation and when their interests are prioritised by the institution (Boaventura et al., 2020).

Given this context, engaging stakeholders in the strategic organisational and educational activities are regarded as the mechanism of leveraging the quality of both management and educational processes. This is achieved through the adoption of new approaches to establishing and maintaining relationships between internal and external educational stakeholders with a focus on benefits they can gain (Bobrytska et al., 2020; Tantalo \& Priem, 2016; Turan et al., 2016).

Therefore, the purpose of the study was to identify how stakeholders of higher education can influence the quality of the educational process and how the stakeholders can effect students' readiness to build a career.

The research questions sought to learn a) how internal and external educational stakeholders such as current students, non-academic and academic staff members, employers, and alumni could help the institutions in addressing the issues related to the curriculum governance, instruction, learning assessment, 
and teaching resources; b) how the adjustments made to the programme influenced the students' readiness to build a career, and c) how the external stakeholders (employers and alumni) evaluated the overall students' professional efficacy while the students were engaged in job internships.

\section{Methods and Materials}

The study was conducted as cross-institutional collaborative research. It utilised mixed methods that made up a mixed-methods sequential explanatory design to expand the evidence base and use triangulation in the confirmation of research output. The qualitative and quantitative methods were employed sequentially the use of quantitative methods was followed by the use of qualitative methods - with the quantitative method predominating (Ivankova et al., 2006; Schoonenboom \& Johnson, 2017).

The baseline phase relied on the survey that used both open-ended and closedended questions (accessible via the link: https://forms.gle/ynKjH6Eg8iBdUx3K6). The purpose was to identify how the internal stakeholders such as current students and non-academic and academic staff members perceived the quality of the educational process with the focus on its effectiveness in fostering students' readiness to embark on a career. The lessons learned from the survey were then used in upgrading the curriculum and instruction methods. Three intervention projects were designed to address the issues related to fostering students' readiness to build a career. These were evaluated by seven experts - instructors, employers, and alumni representatives - using the multi-criteria decision-making method (MCDMM) which is referred to in the literature as the analytic hierarchy process (AHP) (Taherdoost, 2017). One project was selected for the intervention. The university-based part of the intervention stage relied on the data drawn from students' grade point average (GPA), students' academic efficacy rated (reported) by lecturers (teachers), and the Career Competencies Questionnaire (CCQ) adopted from Akkermans et al. (2013) (available via the link: https://forms.gle/HYTAdeyvkeWUWg5t5). The internship part of the intervention was based on the observations and reports of the representatives of the host companies.

\subsection{Research design}

The study utilised the survey research design and quasi-experiment with some features of a descriptive case study such as conducting observations by the external stakeholders and administering measurements (McCombes, 2019; McCombes, 2020). Both quantitative and qualitative data were drawn from the baseline survey. The quantitative data were also drawn from the AHP method and the Career Competencies Questionnaire. The qualitative output was obtained from the reports of lecturers and representatives of the host companies. The design strategy of a mixed-method embedded case study complemented the research methodology by focusing on a single context inquiry while drawing data from multiple sources but within a single context (Coulthard, 2016).

The quasi-experiment was of one-group pre-test - post-test type (McKinley \& Rose, 2020). The study included a baseline survey, transitional phase, quasi- 
experiment consisting of the university-based part and internship part, and an analytical phase (see Fig. 1).

The study was conducted from February 2020 to the end of December 2020 at three higher educational institutions in Ukraine. These were as follows: the National Pedagogical Dragomanov University (NPDU) (Kyiv, Ukraine), the National University of Life and Environmental Science of Ukraine (NULESU) (Kyiv, Ukraine), and the Bogomolets National Medical University (BNMU) (Kyiv, Ukraine). The research focused on three different programmes run at the above institutions, namely Education Studies, Pharmacy, and Computer Engineering. The reason for choosing the programmes was that these suited the research team members' expertise and major subjects.

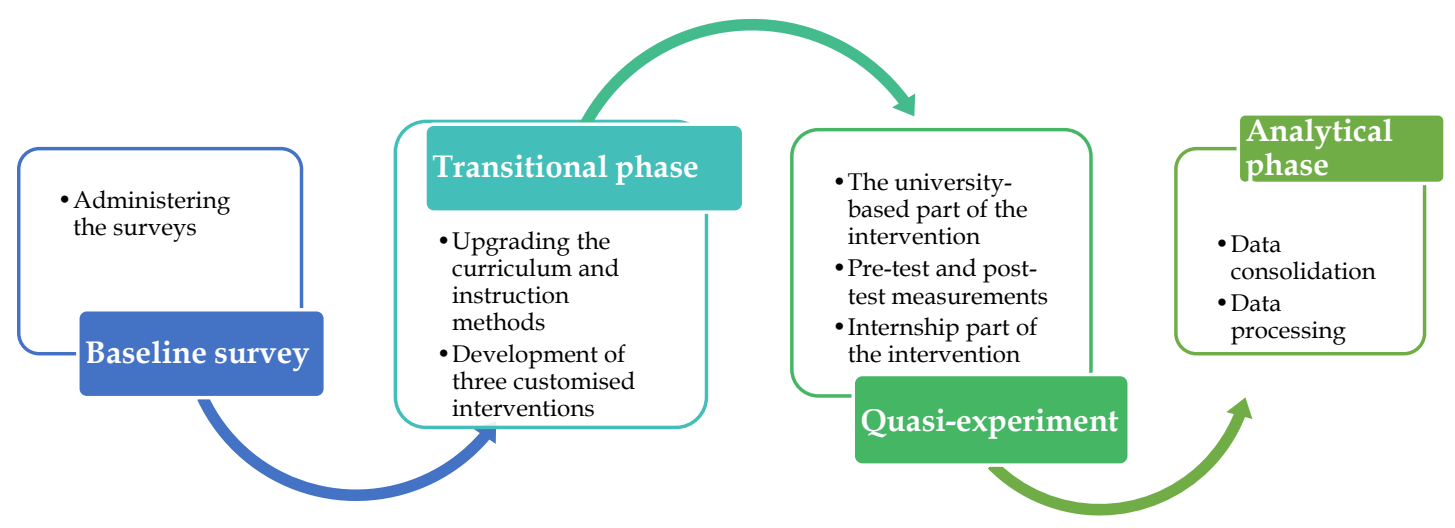

Figure 1: Brief outline of the key phases of the study

\subsection{Descriptions of the programmes}

Table 1 presents the data on programmes such as the title, cycle type, target duration, qualification, and host organisations providing internships for the graduates.

Table 1: Consolidated data on programmes under the scope of the study

\begin{tabular}{|c|c|c|c|c|c|}
\hline $\begin{array}{l}\text { The institution } \\
\text { (person(s) in } \\
\text { charge) }\end{array}$ & $\begin{array}{l}\text { Programme } \\
\text { title }\end{array}$ & Cycle type & 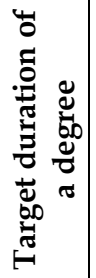 & Qualification & $\begin{array}{l}\text { Host organisations for } \\
\text { internships }\end{array}$ \\
\hline $\begin{array}{l}\text { NPDU } \\
\text { (Dr.T. Olefire } \\
\text { nko) }\end{array}$ & $\begin{array}{l}\text { Education } \\
\text { and } \\
\text { instruction: } \\
\text { Secondary } \\
\text { education, } \\
\text { Technology }\end{array}$ & $\begin{array}{l}\text { Second } \\
\text { cycle } \\
\text { (Master's) } \\
\text { degree }\end{array}$ & 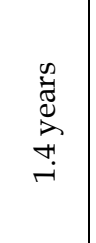 & $\begin{array}{l}\text { Teaching } \\
\text { school } \\
\text { children }\end{array}$ & $\begin{array}{l}\text { State-owned and privately- } \\
\text { owned secondary schools }\end{array}$ \\
\hline
\end{tabular}




\begin{tabular}{|c|c|c|c|c|c|}
\hline $\begin{array}{l}\text { NPDU } \\
\text { (Dr. V. } \\
\text { Bobrytska, } \\
\text { head of the } \\
\text { programme) }\end{array}$ & $\begin{array}{l}\text { Educational } \\
\text { policy }\end{array}$ & $\begin{array}{l}\text { Second } \\
\text { cycle } \\
\text { (Master's) } \\
\text { degree }\end{array}$ & & $\begin{array}{l}\text { Expertise in } \\
\text { education and } \\
\text { instruction; } \\
\text { Consultancy }\end{array}$ & $\begin{array}{l}\text { National Agency for } \\
\text { Quality Assurance of } \\
\text { Higher Education of } \\
\text { Ukraine; } \\
\text { Ministry of Education and } \\
\text { Science of Ukraine; } \\
\text { National Pedagogical } \\
\text { Dragomanov University }\end{array}$ \\
\hline $\begin{array}{l}\text { NULESU } \\
\text { (Dr. } \\
\text { N. Batechko) }\end{array}$ & $\begin{array}{l}\text { Automation } \\
\text { and } \\
\text { computer- } \\
\text { integrated } \\
\text { technologie } \\
\text { s }\end{array}$ & $\begin{array}{l}\text { First and } \\
\text { second } \\
\text { cycle } \\
\text { degrees } \\
\text { (Bachelor' } \\
\text { s and } \\
\text { Master's } \\
\text { degrees) }\end{array}$ & 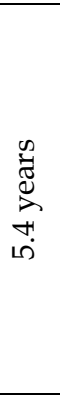 & $\begin{array}{l}\text { Power } \\
\text { engineering, } \\
\text { electrical } \\
\text { engineering, } \\
\text { and } \\
\text { electromechan } \\
\text { ics }\end{array}$ & $\begin{array}{l}\text { Oblenerho } \\
\text { customer services: } \\
\text { "Kyyivoblenerho", } \\
\text { "Cherkasioblenero" } \\
\text { "Rivneoblenergo", } \\
\text { Regional electrical } \\
\text { network offices, } \\
\text { Privately-owned } \\
\text { enterprises in } \\
\text { various industries }\end{array}$ \\
\hline $\begin{array}{l}\text { BNMU } \\
\text { (Dr. T. Reva, \& } \\
\text { Dr.O. Chkhalo) }\end{array}$ & Pharmacy & $\begin{array}{l}\text { Second } \\
\text { cycle } \\
\text { (Master's) } \\
\text { degree }\end{array}$ & 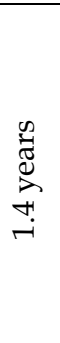 & $\begin{array}{l}\text { Pharmacist, } \\
\text { drug store } \\
\text { manager, } \\
\text { production } \\
\text { line manager, } \\
\text { laboratory } \\
\text { assistant, } \\
\text { tester }\end{array}$ & $\begin{array}{l}\text { "KREOMA-PHARM" } \\
\text { PJSC, } \\
\text { State-owned } \\
\text { Pharmacological Center of } \\
\text { the Ministry of Health of } \\
\text { Ukraine, } \\
\text { "Ekmi" Privately-owned } \\
\text { Enterprise }\end{array}$ \\
\hline
\end{tabular}

\subsection{Description of the interventions (see the executive summaries of the projects in Appendix A)}

Prior to the university-based part of the intervention stage, three projects were designed to upgrade the educational process that focused on fostering students' readiness for career building. The projects were developed by three independent teams involving internal and external stakeholders such as current students, non-academic and academic staff members, employers, and alumni. Each team consisted of between five to seven people. Those people were supposed to deliver their project when it was selected by the board of experts. The projects were expected to meet the groups of criteria such as stakeholder engagement, output quality improvement, career readiness enhancement, sustainability, and societal benefits. These were used by experts as an AHP method when selecting the project for the intervention. The projects were as follows: visiting lectureship, self-branding, and promoting learning-purpose communication cases as a tool to develop specialism skills. The self-branding project was chosen by the experts. Its outcomes were assessed by utilising peer assessment and expert assessment of the students' profiles and content.

\subsection{Sample}

The study population comprised the students of three majors such as Instruction, Engineering, and Medicine along with non-academic and academic staff members. These were selected because they were relevant to the expertise of the research team members. 
Simple random sampling and convenience sampling techniques were used in the course of the research. Random sampling was utilised in the baseline survey to ensure the anonymity of the respondents while convenience sampling was employed to form the experimental groups at the institutions. The baseline study sample consisted of 591 respondents who were current students $(n=538)$ and non-academic and academic staff members $(n=53)$. The respondents for the baseline survey were reached through institutional corporate emailing systems consisting of the link to the Google Forms-based questionnaire. The number of the returned completed questionnaires was used as the number of samples for this phase of the study. The demographic features of the respondents are provided in Table 2.

Table 2: Demographic features of the respondents for the baseline survey $(n=591)$

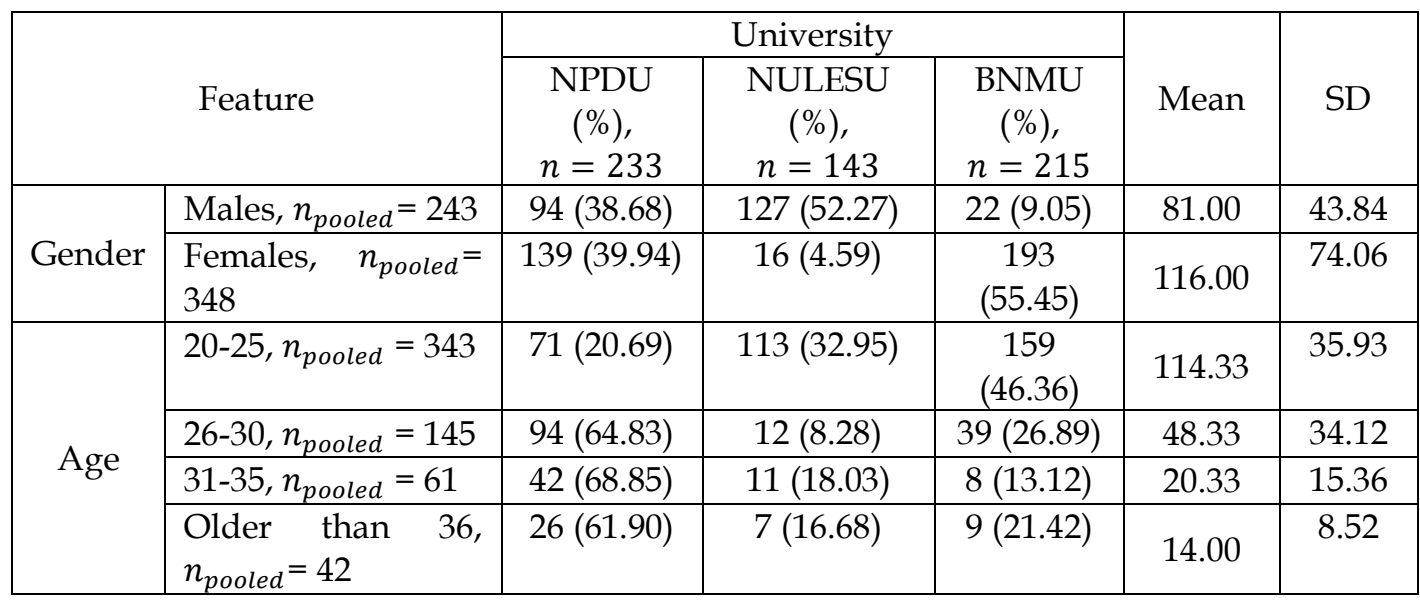

Following that, three student classes from the programmes under the scope of the study were chosen to form experimental groups (EGs). EG 1 for the NPDU consisted of 14 students (4 males and 10 females aged between 23 and 42), $M_{\text {age }}=32.35, \mathrm{SD}=6.90 . \mathrm{EG}_{2}$ for the NULESU involved 25 students (21 males and 4 females aged 21-23), while $M_{\text {age }}=22.16, \mathrm{SD}=0.8 . \mathrm{EG} 3$ for BNMU included 35 students (4 males and 31 females aged 25-36), $M_{\text {age }}=29.74, \mathrm{SD}=3.59$. The total sample size $(n=74)$ was significant at a confidence level of $95 \%$ with the margin of error of $\pm 10.70 \%$. The groups were regarded as mutually homogeneous because the students were studying the same course, their GPA was higher than 75 (ECTS), and the mean values for the CCQ) were 3.58, SD $=0.52$. This suggested that the students underperformed in their career building in terms of their reflections on motivation, qualities, networking, self-profiling, work exploration, and career control. Lecturers' (teachers') feedback on students' academic efficacy (AE) was also considered and it (AE) was rated as satisfactory.

\subsection{Ethical considerations}

The ethical considerations of unintended psychological, financial or social harm that might result from surveys, in-depth interviews, and observations were addressed by ensuring anonymity, confidentiality, and informed consent (Tolich \& Tumilty, 2021). The internal and external educational stakeholders such as current students, non-academic and academic staff members, employers, and alumni provided informed consent before they participated in the human 
interventions. The participants were informed about the exploratory and evaluative purpose of the baseline phase of the study and the voluntary basis of their participation. Privacy and anonymity were ensured by preserving the participants' identity and personal information when collecting and analysing the data and reporting the results of the study. When the survey questionnaires were drafted, they were examined for the existence of discriminatory or offensive wording in order to eliminate it from the questionnaires (Goodwin et al., 2019).

\subsection{Instruments}

The baseline survey questionnaire, the AHP method, the GPA, students' academic efficacy rated (reported) by lecturers (teachers), the CCQ, and observation reports of the representatives of the host companies were used as instruments to yield numerical and non-numerical data.

4.6.1 The baseline survey questionnaire (can be accessed through the link: https://forms.gle/ynKjH6Eg8iBdUx3K6)

The survey was adopted from Northern University Bangladesh (NUB) because it covered the areas under study (Rahman, 2015). It consisted of eight subdomains such as programme governance (8 items), curriculum (4 items), teachinglearning (5 items), learning assessment (6 items), programme admission (3 items), structures and facilities (8 items), student support services (7 items) and research and extension services (4 items). These were followed by two openended questions to determine students' opinions regarding the advantages and disadvantages of the progamme. The respondents used a five-point Likert agreement scale to respond to the rate of their agreement with the core questions.

\subsubsection{Analytic hierarchy process (AHP) method}

The AHP method is a management tool that is used in the decision-making method process (Taherdoost, 2017). For this reason, the method was used by the experts to select three educational projects for the interventions. The criteria for prioritisation of the projects were designed and grouped as follows: a) stakeholder engagement; b) output quality improvement; c) career readiness enhancement; d) sustainability, and e) societal benefits. The two-level hierarchical structure of criteria for evaluating the projects is presented in Figure 2. After the criteria had been specified, the Saaty's comparison (relative importance) scale (2008) that relies on a comparison of two alternatives was used to determine the relative weight of the groups of criteria. The scale uses numerical and reciprocal values from 1 to 9 to indicate the prioritised importance of one group of criteria over the other in a pair of compared groups. When designing the comparison matrix, the recommendation to use the odd numbers rather than the even values was followed. The reason for this was that the calculations using odd numbers provide relatively different measurement values. 


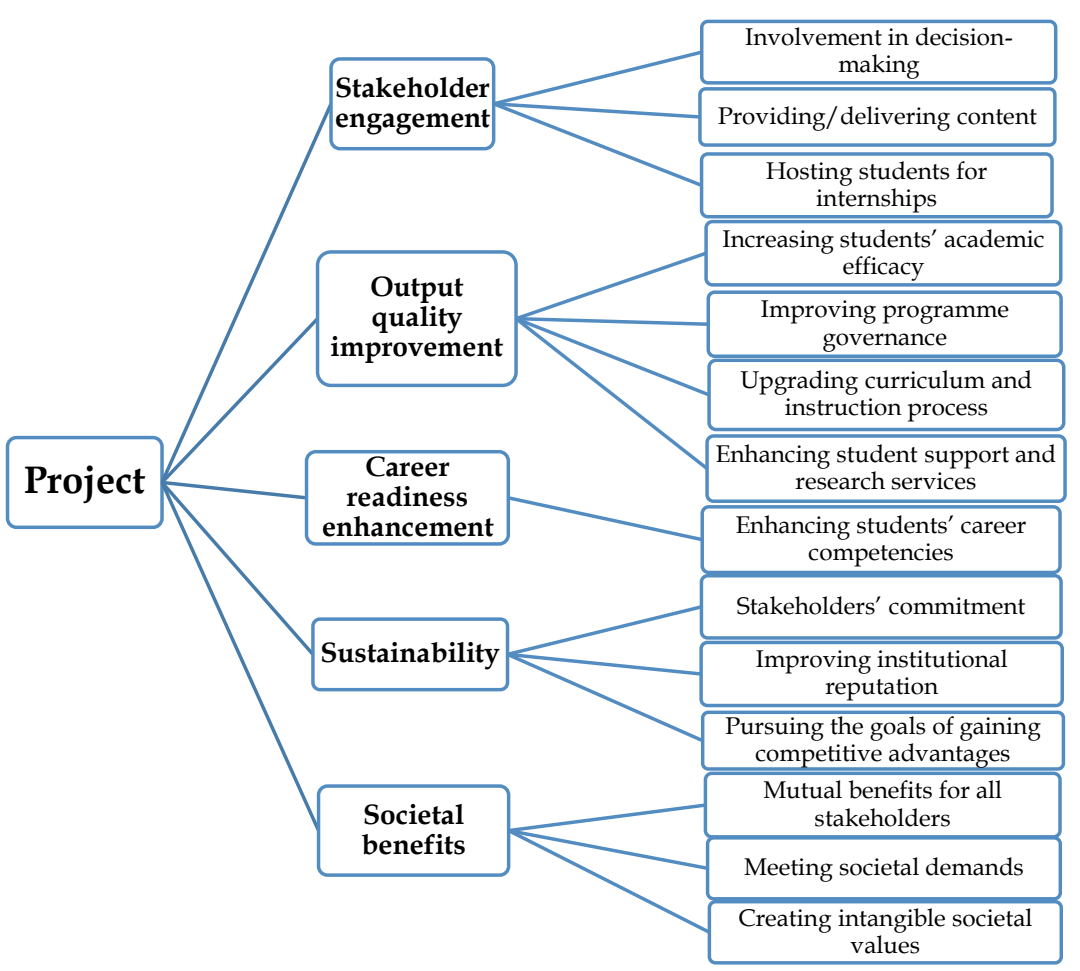

Figure 2: Two-level hierarchical structure of criteria groups for evaluating the projects

Table 3 presents the comparison matrix to determine the relative weight of the groups of criteria.

Table 3: Comparison matrix of the relative weight of the groups of criteria

\begin{tabular}{|c|c|c|c|c|c|}
\hline Criteria group & SE & OQI & CRE & S & SB \\
\hline SE & 1 & $1 / 3$ & $1 / 9$ & $1 / 7$ & $1 / 5$ \\
\hline OQI & 5 & 1 & 1 & 1 & $1 / 3$ \\
\hline CRE & 9 & 7 & 1 & 1 & 5 \\
\hline S & 5 & $1 / 9$ & $1 / 7$ & 1 & 5 \\
\hline SB & 1 & $1 / 5$ & $1 / 9$ & $1 / 7$ & 1 \\
\hline
\end{tabular}

Note: SE - stakeholder engagement; OQI - output quality improvement; CRE - career readiness enhancement; $\mathrm{S}$ - sustainability, and SB - societal benefits.

The normalisation of the comparison matrix aimed at identifying the relative weight to each group of criteria was performed by dividing each table value by the total column value (see Table 4).

Table 4: Normalisation of the comparison matrix

\begin{tabular}{|c|c|c|c|c|c|}
\hline Criteria group & SE & OQI & CRE & S & SB \\
\hline SE & 1 & $1 / 3$ & $1 / 7$ & $1 / 7$ & 3 \\
\hline OQI & 3 & 1 & 1 & 1 & 3 \\
\hline CRE & 9 & 7 & 1 & 1 & 5 \\
\hline S & 5 & $1 / 9$ & $1 / 5$ & 1 & 5 \\
\hline SB & 1 & $1 / 5$ & $1 / 7$ & $1 / 9$ & 1 \\
\hline Total & 18.00 & 8.64 & 2.48 & 3.25 & 17 \\
\hline
\end{tabular}




\begin{tabular}{|c|c|c|c|c|c|}
\hline \multicolumn{7}{|c|}{ Results } \\
\hline SE & $1 / 18=0.055$ & 0.038 & 0.056 & 0.043 & 0.176 \\
\hline OQI & $3 / 18=0.166$ & 0.115 & 0.402 & 0.306 & 0.176 \\
\hline CRE & $9 / 18=0.500$ & 0.808 & 0.402 & 0.306 & 0.292 \\
\hline S & $5 / 18=0.277$ & 0.012 & 0.080 & 0.306 & 0.292 \\
\hline SB & $1 / 18=0.055$ & 0.023 & 0.056 & 0.033 & 0.058 \\
\hline
\end{tabular}

The above was followed by calculation of the priority vector (or eigenvector) indicating the relative value of each croup which was based on computation on the mean value for each group of criteria. The results of the calculations are presented in Table 5.

Table 5: Priority vector (or eigenvector) calculation

\begin{tabular}{|l|l|c|}
\hline Criteria group & \multicolumn{1}{|c|}{ Calculation } & Eigenvector \\
\hline SE & {$[0.055+0.038+0.056+0.043+0.176] / 5=$} & $7.36 \%$ \\
& 0.0736 & \\
\hline OQI & {$[0.166+0.115+0.402+0.306+0.176] / 5=$} & $23.30 \%$ \\
& 0.2330 & \\
\hline CRE & {$[0.500+0.808+0.403+0.306+0.292] / 5=$} & $46.18 \%$ \\
& 0.4618 & \\
\hline S & {$[0.277+0.012+0.080+0.306+0.292] / 5=$} & $19.34 \%$ \\
& 0.1934 & $4.50 \%$ \\
\hline SB & {$[0.055+0.023+0.056+0.033+0.058] / 5=$} & \\
& 0.0450 & \\
\hline
\end{tabular}

As can be seen in Table 5, the relative values of the groups of criteria were distributed as follows: career readiness enhancement (eigenvector $=46.18 \%$ ) was considered the most important criterion in evaluation the projects. The second most important criterion was output quality improvement (eigenvector = $23.30 \%$ ). Sustainability (eigenvector $=19.34 \%$ ) of the project was rated as third important. The least relative value was assigned to the stakeholder engagement and societal benefits criteria. The AHP was validated by several researchers such as Asadabadi et al. (2019), Saardchom (2012), and Saaty (2009).

4.6.3 Career Competencies Questionnaire (CCQ) (borrowed from Akkermans et al., 2013, available via the link: https://forms.gle/HYTAdeyvkeWUWg5t5)

The questionnaire consisted of 21 items distributed under the subscales such as reflection on motivation ( 3 items), reflection on qualities (4 items), networking (4 items), self-profiling (3 items), work exploration (3 items), and career control (4 items). It used the five-point Likert-type agreement scale ranging from $1=$ 'completely disagree' to $5=$ 'completely agree'. The validation procedure used a six-factor CFA model which showed a good fit with values being $x^{2}(171)=$ $261.69, \mathrm{p}<.001 ; \mathrm{CFI}=.95, \mathrm{TLI}=.94, \mathrm{GFI}=.90, \mathrm{RMSEA}=.05$.

\subsubsection{Reports of lecturers and representatives of the host companies}

The reports were consolidated as text and analysed using the Voyant Tools application (can be accessed via the link: https://voyant-tools.org/) which is open-source and used for scholarly reading and interpretation of texts or corpus. 


\section{Results}

The study found the triple benefit of the involvement of internal and external stakeholders in the university educational process. First, it addressed the issues related to curriculum governance, instruction, learning assessment, and teaching resources. It also eliminated the loopholes in lecturers' attempts to foster the students' readiness to build a career. It enabled an objective and unbiased evaluation of the overall students' professional efficacy while the students completed their job internships. The results are presented according to the flow of the research.

\subsection{The baseline survey}

Its purpose was to identify how the internal stakeholders such as current students, and non-academic and academic staff members perceived the quality of the educational process with the focus on its effectiveness in fostering students' readiness to build a career. Figure 3 presents the respondents' perspective displayed as mean values.

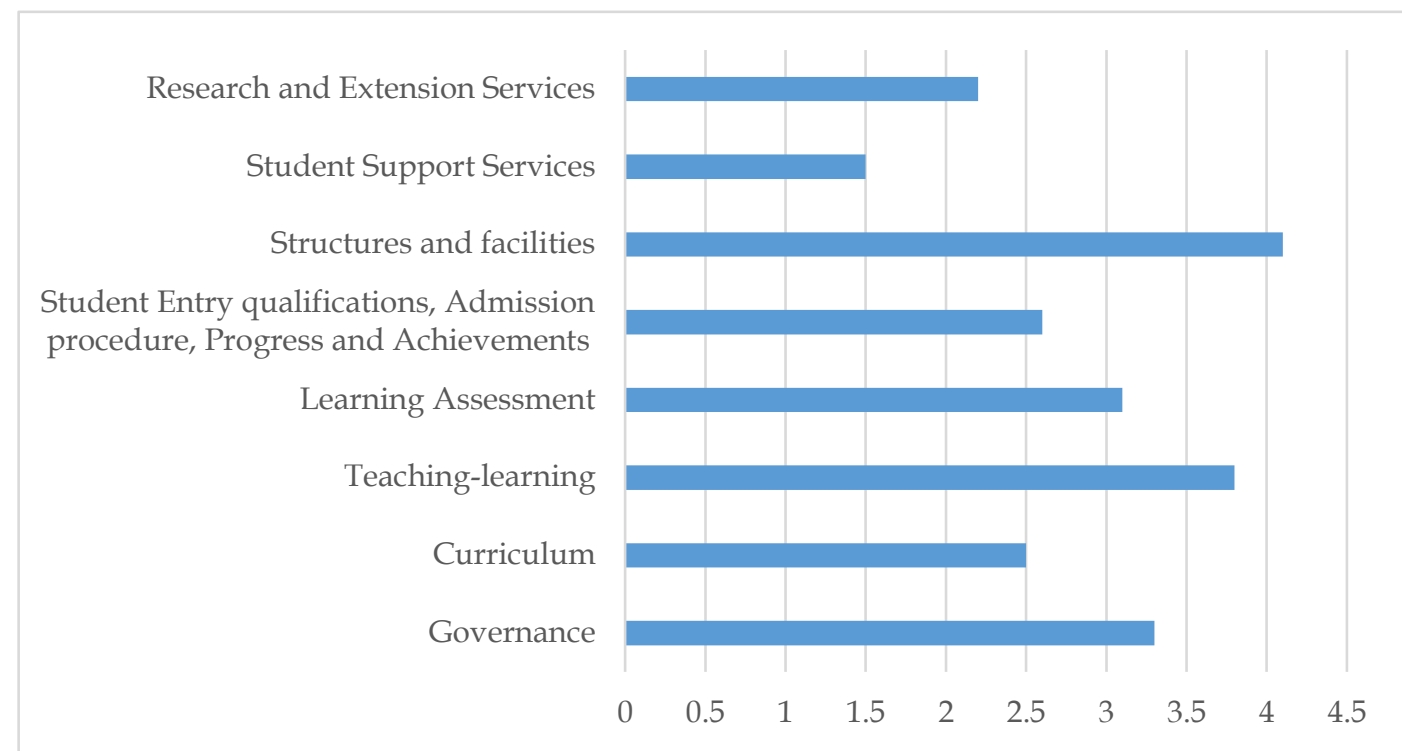

Figure 3: Perspectives of current students and non-academic and academic staff of the quality of educational process displayed as mean values

As can be seen from Figure 3, the overall satisfaction rate of the programmes by students and lecturers was below average with the highest values for structures and facilities $(M=4.2)$ and the lowest ones for student support services $(M=1.5)$. The visual data suggested that students and lecturers rated the quality of student support service $(\mathrm{M}=1.5)$, students' entry qualifications, admission procedure, progress and achievements $(\mathrm{M}=2.7)$, research, and extension services $(\mathrm{M}=2.3)$, and curriculum $(\mathrm{M}=2.5)$ as "second-rate".

The students' and lecturers' most frequent comments on the advantages and disadvantages of the programme were as follows:

[...nice teachers with a positive attitude...]

[...the grades can be negotiated with most teachers...]

[...campus, sports facilities are good...]

[...too much theory and just few practical classes...] 


\section{[...I never know whether my background makes me competitive...] \\ [...assessment system often confuses me...]}

The results yielded from the baseline survey suggested that the intervention was feasible.

\subsection{Results of the selection of the intervention project using the AHP method}

Three intervention projects such as visiting lectureships, self-branding, and promoting learning communication cases (PLCC) were designed to address the issues related to fostering students' readiness to embark on a career. The results of the selection of the project for the intervention performed by seven experts instructors, employers, and alumni representatives - using the AHP method are presented in Figure 4.

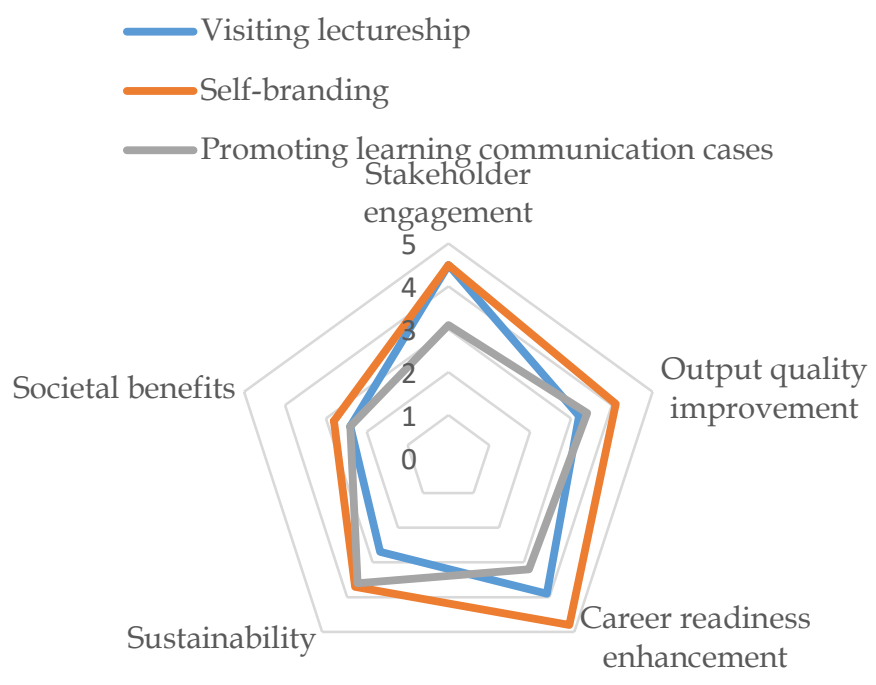

Figure 4: Results of the selection using the AHP method

As can be noted in Figure 4, the self-branding project scored the greatest mean values for all criteria groups and was selected for the intervention.

\subsection{Results drawn from the intervention}

The purpose of the university-based part of the intervention was to identify how students' grades, students' academic efficacy, and their career competencies change owing to the self-branding project. The paired t-test (two-tailed) was used to perform calculations. The descriptive statistics of the intervention are presented in Table 6.

Table 6: Descriptive statistics of the intervention $(n=74)$

\begin{tabular}{|c|c|c|c|c|c|c|c|}
\hline \multirow{2}{*}{ Variable } & \multicolumn{2}{|c|}{ Mean } & \multirow{2}{*}{$\begin{array}{c}S D \text { of } \\
\text { difference }\end{array}$} & \multirow{2}{*}{$p$ normality } & \multirow{2}{*}{$t$} & \multirow[b]{2}{*}{$p$} & \multirow{2}{*}{$d f$} \\
\hline & Before & After & & & & & \\
\hline GPA & 80.4 & 88.66 & \multirow{3}{*}{2.614} & \multirow{3}{*}{0.1366} & \multirow{3}{*}{1.1603} & \multirow{3}{*}{0.0365} & \multirow{3}{*}{73} \\
\hline $\begin{array}{l}\text { Lecturers' } \\
\text { rate }\end{array}$ & 3.52 & 4.02 & & & & & \\
\hline CCQ & 3.58 & 3.918 & & & & & \\
\hline
\end{tabular}


As can be noticed in Table 6, the average difference between the mean values for the variables after the intervention and before was -3.03, suggesting that it positively influenced the students' academic efficiency and career development skills. The test statistic T equals 1.1603, which is in the $95 \%$ region of acceptance: [ $-4.3027: 4.3027]$ while $\bar{x}=3.03$, is in the $95 \%$ region of acceptance:

[-1.2458:11.2458]. The mean value for the effect size $d$ was 0.67 , indicating that it was large and statistically significant.

\subsection{Internship part of the intervention}

The observation reports of the representatives of the host companies were consolidated as a text corpus and analysed using the Voyant Tools software. The words 'work', 'skills', 'great', 'excellent', and 'learn' were the most frequent words in the corpus. The most frequent colocations in the reports were as follows: 'accomplished workers', 'beyond expectations', 'high quality', 'a valuable asset', and 'confident professionals'. The above implied that the representatives of the host companies were generally delighted with the quality of occupational readiness of the students. Some of the quotes were as follows:

[... a student is a quick learner with initiative in all aspects of working...]

[...did an excellent job... is adaptive, ready to challenges and changes

that we experienced...]

[...will make someone at some company...]

[...demonstrated a good base knowledge...]

[... will achieve success in whatever endeavors they decide to pursue...]

Limitations

The key limitation is related to the use of the one-group-only quasi-experimental treatment. It lacked the control group for comparative evaluation of the outcomes.

\section{Discussion}

The strength of the study lies in involving stakeholders in the transformation of the educational process and the curriculum in the way these foster the fostering students' readiness to embark on a career. The results yielded from the study proved the triple benefit of the involvement of internal and external stakeholders in the university educational process. First, it comprehensively addressed the issues related to curriculum governance, instruction, learning assessment, and teaching resources. It also eliminated the loopholes in lecturers' attempts to foster the students' readiness to build a career. It further enabled an objective and unbiased evaluation of the overall students' professional efficacy while the students completed their job internships.

The baseline survey showed that the overall satisfaction with the programmes as rated by students and lecturers was below average with the highest values for the 'structures and facilities' area of evaluation and 'student support services' being rated the lowest. The results yielded at this phase suggested that the intervention was feasible. The self-branding project was scored the highest by the experts and was selected for the intervention. It implied that this project best corresponded to the study objectives. The results of pre-and post-intervention 
measurements of students' GPA, academic efficacy, and career competencies showed the average difference between the mean values for the variables after the intervention and before it was -3.03. This suggested that it positively influenced the students' academic efficiency and career development skills. The test statistic $\mathrm{T}$ equals 1.1603, which is in the 95\% region of acceptance: [4.3027:4.3027]. $\bar{x}=3.03$, is in the $95 \%$ region of acceptance: [-1.2458:11.2458]. The mean value for the effect size $d$ was 0.67 , indicating that it was large and statistically significant.

The observation reports of the representatives of the host companies confirmed the effectiveness of the self-branding project in fostering students' readiness to embark on a career. The words 'work', 'skills', 'great', 'excellent', 'learn' were the most frequently used words in the corpus of the reports. The most frequent collocations in the reports were 'accomplished workers', 'beyond expectations', 'high quality', 'a valuable asset', and 'confident professionals'. The above implied that the representatives of the host companies were generally pleased with the quality of occupational readiness of the students.

The findings drawn for the survey, measurements, and observations agree with the previous research. These are consistent with the findings of Nizhenkovska et al. (2020) reporting that the project-based learning of the graduates fosters their self-directed learning skills and enhances their readiness for career building. The implications align with the views of Bobrytska et al. (2020), who found that the bottom-up approach that is related to involving all stakeholders in shaping institutional educational policy is a promising trend in Ukraine. Furthermore, the findings are in agreement with those of Khan and Zhang (2017) who view the visiting lectureship as leverage in upgrading the educational process and curriculum to engage students in building their career and public image. The study aligns with the results of a study by Collins (2012) who proved that selfbranding is not just a commercial phenomenon; it also promotes the reputation of a person or organisation, and it helps in a person's career development and success.

\section{Conclusion}

The study found the triple benefit of the involvement of internal and external stakeholders in the university educational process. First, it addressed the issues related to curriculum governance, instruction, learning assessment, and teaching resources. It also eliminated the loopholes in lecturers' attempts to foster the students' readiness to build a career. It enabled the objective and unbiased evaluation of the overall students' professional efficacy while the students completed their job internships. The self-branding project was viewed by all stakeholders as the optimal way to foster students' readiness to build a career through involving stakeholders in upgrading the educational process and instruction. The baseline survey showed that the overall satisfaction rate of the programmes by students and lecturers was below average with the highest values for structures and facilities and the lowest ones for student support services. The self-branding project showed the average difference between the mean values for the variables after the intervention and before it as -3.03 . That suggested that it positively influenced the students' academic efficiency and career development skills. The mean value for the effect size $d$ was 0.67 , 
indicating that it was large and statistically significant. The observation report provided by representatives of the host organisations implied that the representatives of the host companies were generally pleased with the quality of occupational readiness of the students. The students reported that they felt more confident in communicating with their colleagues-to-be, planning their job activities, and performing job-related tasks.

Further research is needed in training the students in the self-marketing of their brands. The implication of the study for future research is that the educational policy and practice need to rethink ways of involving internal and external stakeholders in the university educational process in terms of building longterm relationships and sharing responsibility for the quality of the professional training of the students.

\section{Recommendations}

It is recommended that the students should start building their brand as soon as they commence their studies at university. They are expected to learn to use social media such as Facebook, Instagram, and LinkedIn for this purpose. In addition, the students should subscribe to several experts' pages, blogs, or professional communities to gain experience and enhance their expertise. The instructors are advised to set an example for their students to follow and share their experiences.

\section{Acknowledgement}

We are thankful to students, staff members, employers, and alumni students for their whole-hearted support in every phase of the study to make it flow smoothly and be scientifically significant.

\section{Conflicts of Interest}

The authors do not have any conflicts of financial or research presentationrelated interest to declare.

\section{References}

Abelha, M., Fernandes, S., Mesquita, D., Seabra F., \& Ferreira-Oliveira, A. T. (2020). Graduate employability and competence development in higher education - A systematic literature review using PRISMA. Sustainability, 12(15), 1-27. https://doi.org/10.3390/su12155900

Akkermans, J., Brenninkmeijer, V., Huibers, M., \& Blonk, R. W. B. (2013). Competencies for the contemporary career: Development and preliminary validation of the career competencies questionnaire. Journal of Career Development, 40(3), 245-267. https:// doi.org/10.1177/0894845312467501

Alismail, H. A., \& McGuire, P. (2015). 21 ${ }^{\text {st }}$ century standards and curriculum: Current research and practice. Journal of Education and Practice, 6(6), 150-155. https:// files.eric.ed.gov/fulltext/EJ1083656.pdf

Asadabadi, M. R., Chang, E., Saberi, M., \& Zhou, Z. (2019). Are MCDM methods useful? A critical review of the analytic hierarchy process (AHP) and the analytic network process (ANP) (Rev. ed.). Cogent Engineering, 6(1), 1-11. https://doi.org/10.1080/23311916.2019.1623153 
Bilodeau, L., Podger, J., \& Abd-El-Aziz, A. (2014). Advancing campus and community sustainability: Strategic alliances in action. International Journal of Sustainability in Higher Education, 15(2), 157-168. https:// doi.org/10.1108/ijshe-06-2012-0051

Beerkens, M., \& Udam, M. (2017). Stakeholders in higher education quality assurance: Richness in diversity? Higher Education Policy, 30(3), 341-359. https:// doi.org/10.1057/s41307-016-0032-6

Bobrytska, V., Luzik, E., Reva, T., Spitsin, Y., \& Akmaldinova, V. (2020). Involving stakeholders in shaping educational legislation and policy in Ukraine. European Journal of Educational Research, 9(3), 1189-1200. https://doi.org/10.12973/eujer.9.3.1189

Boaventura, J. M. G., Bosse, D. A., De Mascena, K. M. C., \& Sarturi, G. (2020). Value distribution to stakeholders: The influence of stakeholder power and strategic importance in public firms. Long Range Planning, 53(2), 1-18. https:// doi.org/10.1016/j.lrp.2019.05.003

Borg, J., Turner, M., \& Scott-Young, C. (2017). Fostering student work readiness: A university case study. In: M. Lamb (Ed.), Proceedings of the 41st Australasian Universities Building Education Association Conference (pp. 196-209). Australasian Universities Building Education Association. https://doi.org/10.29007/n8wn

Busteed, B. (2015). America's 'No Confidence' vote on college grads' work readiness. Gallop. https://news.gallup.com/opinion/gallup/182867/america-no-confidence-votecollege-grads-work-readiness.aspx

Carpio, X. D., Kupets, O., Muller, N., \& Olefir, A. (2017). Skills for a modern Ukraine. Directions in development. World Bank. http://dx.doi.org/10.1596/978-1-46480890-6

Collins, B. (2012). The importance of personal branding: Uses of personal branding for career development and success. (Bachelor's degree thesis, California Polytechnic State University).

https://digitalcommons.calpoly.edu/cgi/viewcontent.cgi?referer=https://ww w.google.com / \&httpsredir $=1$ \&article $=1048 \&$ context=joursp

Coulthard, G. J. (2016). A descriptive case study: Investigating the implementation of webbased, automated grading and tutorial software in a freshman computer literacy course. (Doctoral dissertation thesis, Purdue University). Open Access Dissertations. 917. https://docs.lib.purdue.edu/open_access_dissertations/917

Costa, P., \& Araújo, L., (2018). Quality of Teaching and Learning in Science. EUR 28865 EN. Luxembourg: Publications Office of the European Union. https://doi.org/10.2760/860512

Didham, R. J., \& Ofei-Manu, P. (2020). Facilitating collaborative partnerships in education policy research: A case of multi-stakeholder, co-investigation for monitoring and evaluation of education for sustainable development. Sustainability, 12(7), 1-15. https://doi.org/10.3390/su12072787

Fagrell, P., Fahlgren, A., \& Gunnarsson, S. (2020). Curriculum development and quality work in higher education in Sweden: The external stakeholder perspective. Journal of Praxis in Higher Education, 2(1), 28-45. http://jphe.org/wpcontent/uploads/2020/07/Fagrell-Fahlgren-Gunnarsson.pdf

Ferrero-Ferrero, I., Fernandez-Izquierdo, M. A., Mucoz-Torres, M. J., \& Belles-Colomer, L. (2018). Stakeholder engagement in sustainability reporting in higher education: An analysis of key internal stakeholders' expectations. International Journal of Sustainability in Higher Education, 19(2), 313-336. https://doi.org/10.1108/ijshe-06-2016-0116 
Filho, W. L., \& Brandli, L. (Eds.) (2016). Engaging stakeholders in education for sustainable development at university level. Cham, Switzerland: Springer. https:// doi.org/10.1007/978-3-319-26734-0

Franco, M., Silva, R., \& Rodrigues, M. (2019). Partnerships between higher education institutions and firms: The role of students' curricular internships. Industry and Higher Education, 33(3), 172-185. https://doi.org/10.1177/0950422218819638

Freeman, R. E., Phillips, R., \& Sisodia, R. (2020). Tensions in stakeholder theory. Business and Society, 59(2), 213-231. https://doi.org/10.1177/0007650318773750

Goins, A. (2018). Why job readiness matters in higher ed. Kenzie Academy. https://www.kenzie.academy/blog/why-job-readiness-matters-in-higher-ed/

Goodwin, D., Mays, N., \& Pope, C. (2019). Ethical issues in qualitative research. In N. Mays, \& C. Pope, Qualitative Research in Health Care (4th ed.). (pp. 27-41), John Wiley \& Sons (Chapter 3). https://doi.org/10.1002/9781119410867.ch3

Graham, R., Freng, H.A., Freng, E.C., Freng, P.G., David, P., Crawley, E., President, F., David, G., \& Freng (2012). Achieving excellence in engineering education: The ingredients of successful change. London: Royal Academy of Engineering. https://www.raeng.org.uk/publications/reports/achieving-excellence-inengineering-education

Ivankova, N. V., Creswell, J. W., \& Stick, S. L. (2006). Using mixed-methods sequential explanatory design: From theory to practice. Field Methods, 18(1), 3-20. https://doi.org/10.1177\%2F1525822X05282260

McKinley, J., \& Rose, H. (Eds.). (2020). Experimental and quasi-experimental designs. In: J. McKinley \& H. Rose (Eds.), The Routledge Handbook of Research Methods in Applied Linguistics. London: Routledge. https://doi.org/10.4324/9780367824471

Khan, S. A. R., \& Zhang, Y. (2017). The effective role of visiting lecturers in the courses of supply chain management. American Journal of Traffic and Transportation Engineering, 2(6), 104-109. https:/ / doi.org/ 10.11648/j.ajtte.20170206.12

Langrafe, T. D. F., Barakat, S. R., Stocker, F., \& Boaventura, J. M. G. (2020). A stakeholder theory approach to creating value in higher education institutions. The Bottom Line, 33(4), 297-313. https:// doi.org/10.1108/BL-03-2020-0021

Lynch, M. (2017). Creating real-world connections and fostering college and career readiness. The Advocate. https://www.theedadvocate.org/creating-real-worldconnections-and-fostering-college-and-career-readiness/

Magalhães, A., Veiga, A., \& Amaral, A. (2018). The changing role of external stakeholders: From imaginary friends to effective actors or non-interfering friends. Studies in Higher Education, 43(4), 737-753. https:// doi.org/10.1080/03075079.2016.1196354

McCombes, S. (2019). Descriptive research. Scribbr. https://www.scribbr.com/methodology/descriptive-research/

McCombes, S. (2020). How to create a research design. Scribbr. https://www.scribbr.com/research-process/research-design/

Nizhenkovska, I., Reva, T., Chkhalo, O., \& Holovchenko, O. (2020). Technology-driven self-directed learning of graduate pharmaceutists: Adding value through entrepreneurship. International Journal of Learning, Teaching and Educational Research, 19(6), 111-126. https:// doi.org/10.26803/ijlter.19.6.7

Organisation for Economic Co-operation and Development (OECD) Eurasia (2015). Identifying and addressing skills gaps in Ukraine. Paris: OECD. https://www.oecd.org/eurasia/competitiveness-programme/easternpartners/Skills_Gap_Assessment_Ukraine_ENG.pdf 
Perna, M. C. (2020). Let's make students career ready - Period. Forbes. https://www.forbes.com/sites/markcperna/2020/01/28/lets-make-studentscareer-readyperiod/?sh=d79bfc1de0f3

Rahman, L. (2015). Through lens of major stakeholders: Progress of Faculty of Business. Northern University Bangladesh 10-13. https://www.slideshare.net/sohagsikder1/generalized-survey-tools-forprogram-self-assessment-1

Saaty, T. L. (2008). Relative measurement and its generalization in decision making: Why pairwise comparisons are central in mathematics for the measurement of intangible factors. The analytic hierarchy/network process. Review of the Royal Spanish Academy of Sciences, Series A, Mathematics, 102(2), 251-318. https:/ / doi.org/10.1007/bf03191825

Saaty, R. (2009). Validation examples for the analytic hierarchy process and the analytic network process. In W. Adamus (Ed.), The analytic hierarchy and network processes: Application in solving multicriteria decision problems (pp. 39-62). Jagiellonian University Press.

Saardchom, N. (2012). The validation of the analytic hierarchy process (AHP) scoring model. International Journal of Liability and Scientific Enquiry, 5(2), 163-166. https://doi.org/10.1504/ijlse.2012.048472

Savga, L., Krykliy, O., \& Kyrychenko, K. (2018). The role of internal and external stakeholders in the higher education system in Ukraine. Business Ethics and Leadership, 2(1), 32-43. https:/ / doi.org/10.21272/ bel.2(1).32-43.2018

Schoonenboom, J., \& Johnson, R. B. (2017). How to construct a mixed-methods research design. Journal for Sociology and Social Psychology / Kolner Zeitschrift fur Soziologie und Sozialpsychologie], 69(2), 107-131. https://doi.org/10.1007/s11577-017-0454-1

Taherdoost, H. (2017). Decision making using the analytic hierarchy process (AHP): A step by step approach. International Journal of Economics and Management Systems, 2(1), 1-4. https:/ / ssrn.com/abstract=3224206

Tantalo, C., \& Priem, R. L. (2016). Value creation through stakeholder synergy. Strategic Management Journal, 37(2), 314-329. https:/ / doi.org/10.1002/smj.2337

Tolich, M., \& Tumilty, E. (2021). Finding our ethical research self: A guidebook for novice qualitative researchers. London: Routledge. https:// doi.org/10.4324/9780429056994

Turan, F. K., Cetinkaya, S., \& Ustun, C. (2016). A methodological framework to analyze stakeholder preferences and propose strategic pathways for a sustainable university. Higher Education, 72(6), 743-760. https:/ / doi.org/10.1007/s10734-0159973-8

Ulewicz, R. (2017). The role of stakeholders in quality assurance in higher education. Human Resources Management \& Ergonomics, 9(1), 93-107.

Wiśniewska, M., Szymańska-Brałkowska, M. \& Zieliński, G. (2014). Determinanty jakości ustug edukacyjnych [Determinants of education services quality]. Research papers of Wrocław University of Economics/Prace Naukove, 271-280. https://doi.org/10.15611/pn.2014.354.25

Yamashita, G. L., \& Cheang, M. (2019). Moving from the classroom to practice: University student interns' readiness for the workplace. In L. Gómez Chova, A. López Martínez, \& I. Candel Torres (Eds.), Proceedings for the 13th International Technology, Education and Development Conference (pp. 1227-1238). https://doi.org/10.21125/inted.2019.0394 


\section{Appendix A: Executive summary of the projects for the intervention}

\section{Visiting Lectureship}

This project was planned to last two semesters. The purpose was to involve the employers and alumni in curriculum upgrade and instruction. The employers and alumni were also supposed to provide at-request consultancy to the students. The students and academic staff members were involved in the selection of the four to five guest speakers and visiting lecturers through polling and voting. They were expected to be 30 to 50 years old, have relevant background and experience of more than six years, have a strong brand in social media, and be charismatic. The guest speakers and visiting lecturers were further expected to have a plan of events and present it to the students. The host organisations for internships were also selected through voting.

\section{Self-branding}

The marathon format was supposed to be used to involve current students, academics, employers, and alumni in a cooperative learning process design and delivery. The process was based on developing students' skills in professional storytelling based on/according to their professional background, management of reputation, and tracking the growth of their brand in Facebook, Instagram, LinkedIn, and YouTube. The guest speakers and visiting lecturers (employers and alumni) were to be selected and involved in training the students in career building, copywriting, framed messaging, persuasion, video making, and editing. The guest speakers and visiting lecturers should also deliver professional purpose lectures, workshops, and labs. Self-branding-purpose videos, webinars, or Zoom (Google Meet, Webex) sessions were supposed to be conducted to train students and evaluate their work. The incorporated statistical tools were employed to analyse and track the effectiveness of the students' work. Telegram app was utilised to manage and facilitate the class.

\section{Promoting learning communication cases as a tool to develop specialism skills}

These were expected to deepen students' professional knowledge and skills through the use of cases that were delivered and interpreted by employers or alumni representatives. Each case relied on five components such as the introduction of the concept (case), reflection, consolidation, information-inquiry stimulation, and skills training. The students were expected to complete the research assignments followed by writing essays, participating in a debate (discussion), or delivering a presentation. Simulations were to involve the students in experiencing their career development skills and job functions. 